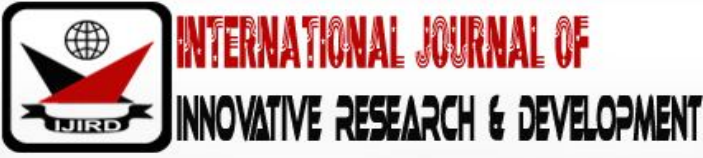

ISSN 2278 - 0211 (Online)

\section{GC-MS, Phytochemical and Antimicrobial Analysis of the Leaf of Newbouldia Laevis (P.Beav)}

Iwu Irenus .C
Senior Lecturer, Department of Chemistry, Federal University of Technology Owerri, Nigeria
Maureen Chijioke Okere
Lecturer, Department of Chemistry, Federal University of Technology Owerri, Nigeria
Onu Uchenna Linda
Lecturer, Chemistry Department, Federal University of Technology Owerri, Nigeria
Rosemary Uchegbu
Senior Lecturer, Alvan Ikokwu Federal College of Education, Owerri Nigeria

\begin{abstract}
:
The leaf of Newbouldia laevis were analyzed for its phytochemical and anti-microbial properties with the aid of; Shimazu Japan GC model 5890-11, GC-MS QP 2010 PLUS Shimazu Japan and Jenway digital Spectrophtometer model 6303. The GC-MS analysis of this sample gave the following compounds; 2- phenoxy ethyl beta -2-phenoxy ethyl-3-phenyl propanoate (1.41\%), benzene-(1-methyl nonadecyl) (1.41\%), 6-phenyl undecane (1.06\%), Eicosyne (2.47\%), hexadecanoic acid methyl ester $(13.73 \%)$, n-hexadecanoic acid (9.16\%), z-octadecanoic acid (22.81 \%),9-octadecanoic acid (22.81 \%) phytol (23.51 \%) Oleic acid (10.56 \%), octadecanoic acid. (5.97\%), squalene (7.75\%). The phytochemical composition of the sample showed that the alkaloid composition was $0.48 \%$, with corresponding values of $0.86 . \%, 0.66 \%, 0.024 \%$ and 0.86 ppm for flavonoids ,saponins, phenols and tannins respectively The extracts showed marked inhibition of the growth of seven selected pathogens; Pseudomonas aeruginosa $12 \mathrm{~mm}$, Staphylococcus aureus $13 \mathrm{~mm}$, Escherichia coli $15 \mathrm{~mm}$, Salmonella typhi $17 \mathrm{~mm}$, Candida albican $11 \mathrm{mms}$, Aspergillus niger $14 \mathrm{~mm}$ and Penicillium $12 \mathrm{~mm}$ with minimum inhibitory concentrations of $6.5 \mathrm{mg} / \mathrm{cm}^{3}, 12.5$ $\mathrm{mg} / \mathrm{cm}^{3}, 12.5 \mathrm{mg} / \mathrm{cm}^{3}, 6.5 \mathrm{mg} / \mathrm{cm}^{3}, 12.5 . \mathrm{mg} / \mathrm{cm}^{3}, 12.5 \mathrm{mg} / \mathrm{cm}^{3}$ and $6.5 \mathrm{mg} / \mathrm{cm}^{3}$ respectively
\end{abstract}

Keywords: Newbouldia laevis, phytochemical, alkaloid, flavonoids, saponins pathogens

\section{Introduction}

Newbouldia laevis_is a common plant of the tropics known as Adurukuae in Hausa, Ogirishi in Igbo and Akoka in Yoruba language. It is a medium sized angiosperm which belongs to the bignoniaceae family. Its bark is chewed and swallowed to heal stomach pain, diarrhea and toothache. (Lewis and manony, 1977, Amaechina. 2003). The extracts of this plant are used for the treatment of elephantiasis, dysentery, rheumatic swellings, syphilis, constipation, pile and as a vermifuge for round worms. It is also useful for the treatment of ear ace, sore foot, chest pain, epilepsy and convulsion. (Akunyili, 2000), The leaf, stem and fruits have been used for febrifuge, wound dressing and for stomach ace (lwu, 2000). The plant is a multipurpose one and its leaves, fruits and flowers, bark and roots have various medicinal value. Studies by (Oliver-Bever, 1986) revealed that the leaf and bark contain flavonoids, saponins, quinines, terpenes and steroids. Recent studies have revealed the presence of alkaloids, quinoids, phenyl propanoids amongst other chemicals. The usefulness of the crude extracts of Newbouldia laevis in pharmacological preparations is receiving far reaching attention. (Enitone, et al 2010) carried out studies on the uterine wall stimulatory effect of the ethanolic leaf extract of Newbouldia laevis and concluded that the extracts have the potency of inducing the contraction of the uterine wall of pregnant rats. Usman and Osuji (2007) analyzed the usefulness of the methanolic extract in treatment of certain body disorder. Their work showed that the extract could be used to treat stomach disorder, diarrhea, dysentery and as a remedy for the treatment of wounds. Works by (Amechina, 2003) indicated that the aqueous leaf extract is potent remedy against dental caries. In her contribution, (Akunyili, 2000) related the treatment of sore foot, chest pain, epilepsy, and convulsion to the use of extract from Newbouldia laevis. Her views were supported by Iwu (2000) whose work indicated the usefulness of the leaf, stem and fruit of the plant for the treatment of stomach ache and for wound dressing, (Okwu and Orji, 2004) Works by (Tanko et al, 2008) has shown that the ethanolic flower extract of this plant has both antinociceptive and anti-inflammatory properties. The flower of the plant has anti-diabetic activity. Usman and Osuji (2007) investigated on the leaf of the plant and found that it has good property and can act as a cheap antibacterial source. 
(Amos et al, 2002) demonstrated that the leaf extract has sedative properties. They found that the methanol leaf extract caused considerable reduction of exploratory activity and prolonged pentobarbitone induced hypnosis in rats. They also found that the extract attenuates apomorphine climbing in rats. In Nigeria and Ghana, the use of the stem bark for the treatment of breast tumour is a common practice, (Banhil et al, 1985).

The root and leaf extracts have been shown to have antimalarial properties. Works by (Ogunlana and Ogunlana,2008) indicated that the ethanolic stem bark extract of Newbouldia Laevis exhibits antioxidant activity. According to them the total phenolic content, antioxidant activity and reducing power of the extract have direct relationship. The plant extracts have been used in the treatment of elephantiasis, dysentery, rheumatic swelling, syphilis and many other disorders. (Akunyili, 2000). The stem, leaves and fruits have been used as febrifuges, in wound dressing and treatment of stomach ache. (Iwu, 2000). This plant exhibits these properties due to the presence of phytochemicals in them. Phytochemicals are plant secondary metabolites. Plant chemicals are divided into primary and secondary metabolites depending on their role in plant metabolism. (Okwu ,2004). These secondary metabolites comprise of alkaloids, saponins, tannins, flavonoids, steroids, terpenoids and phenolic compounds, these substances have been used as food, drugs, food additives, fragrances, insecticides and other chemicals (Okwu and Orji, 2004)

\section{Materials and Method}

\subsection{Plant Materials}

The leaves and bark of the samples were obtained from the tree of Pentaclethra macrophylla and Newbouldia laevis in Ezinihitte Mbaise area of Imo state, Nigeria, washed with distilled water and sun dried. The dried samples were milled with an electric milling machine and stored in air tight plastic bottles and kept for analysis.

\subsection{Alkaloid Determination}

$5 \mathrm{~g}$ of the sample was weighed into a $250 \mathrm{~cm}^{3}$ beaker and $200 \mathrm{~cm}^{3}$ of $29 \%$ acetic acid in ethanol was added and covered to stand for $6 \mathrm{hrs}$. This was filtered and the extract was concentrated using a water bath to one quarter of the original volume. The Alkaloid was precipitated out using concentrated ammonium hydroxide which was added drop by drop until precipitation was complete. The solution was allowed to settle and the precipitation was collected by filtration using Whatman filter paper, the precipitate was dried and weighed (Obadoni and Ochuko (2001).

\subsection{Saponin Determination}

$20 \mathrm{~g}$ of the sample was weighed into a $250 \mathrm{~cm}^{3}$ beaker and $200 \mathrm{~cm}^{3}$ of $20 \%$ ethanol was added and stirred using a glass rod. The mixture was heated over water bath for $4 \mathrm{hrs}$ with continuous stirring while the temperature was maintained at $55{ }^{\circ} \mathrm{C}$. The mixture was extracted and the residue was extracted with $200 \mathrm{~cm}^{3}$ of $20 \%$ ethanol. The combined extract was reduced to $40 \mathrm{~cm}^{3}$ over water bath at $90{ }^{\circ} \mathrm{C}$. The concentrated extract was transferred into a $250 \mathrm{~cm}^{3}$ separation funnel and 20 $\mathrm{cm}^{3}$ of diethyl ether was added and shaken vigorously. The aqueous layer was recovered while the ether layer was discarded. This process was repeated thrice. $60 \mathrm{~cm}^{3}$ of n-butanol was added. The mixture was washed twice with $10 \mathrm{~cm}^{3}$ of $5 \%$ sodium chloride. The remaining solution was heated over water bath and the residue dried to constant weight. The saponin content was calculated in percentages (Obadoni and Ochuko 2001).

\subsection{Flavonoid Determination}

$10 \mathrm{~g}$ of the plant sample were extracted repeatedly with $100 \mathrm{~cm}^{3}$ of $80 \%$ of aqueous methanol at room temperature. The solution obtained was filtered with whatman filter paper no 45. The filtrates were later transferred into a crucible and evaporated to dryness over a water bath and weighed (Boham and Kocipai,1994)

\subsection{Phenol Determination}

$2 \mathrm{~g}$ of the sample was defatted with $100 \mathrm{~cm}^{3}$ of diethyl ether using a soxhlet apparatus for two hours. The defatted sample was boiled within $50 \mathrm{~cm}^{3}$ of ether for 15 minutes, then $5 \mathrm{~cm}^{3}$ of the extract was pipetted into a $50 \mathrm{~cm}^{3}$ flask and $10 \mathrm{~cm}^{3}$ of distilled water was added. $2 \mathrm{~cm}^{3}$ of ammonium hydroxide and $5 \mathrm{~cm}^{3}$ of amyl alcohol were added. The samples were made up to the mark and left for colour development. The absorbance of the solution was measured using Labtech digital spectrophotometer at $505 \mathrm{~nm}$ wavelength (Obandoni and Ochuko 2001, Harbone 1973)

\subsection{Tannin Determination}

$0.5 \mathrm{~g}$ of the sample was weighed into $250 \mathrm{~cm}^{3}$ beaker and $50 \mathrm{~cm}^{3}$ of distilled water was added and stirred vigorously with a glass rod for one hour the solution was filtered into a $50 \mathrm{~cm}^{3}$ volumetric flask and made up to the mark. $5 \mathrm{~cm}^{3}$ of the filtrate was pipetted into a test tube and mixed with $3 \mathrm{~cm}^{3}$ of O.I $\mathrm{M} \mathrm{FeCl}_{3}$ in O.IN HCI and $0.008 \mathrm{M}$ Potassium Ferro cyanide. The absorbance was measured with the Labtech digital spectrophotometer at $120 \mathrm{~nm}$ wave length. The absorbance was compared with those of standard made from tannic acid (Van-Burden and Robinson 1981) 


\subsection{Preparation of Samples for GC-MS Analysis}

Two hundred grams of each sample was repeatedly extracted with ethanol using soxhlet extractor, another $200 \mathrm{~g}$ of each sample was soaked in ethanol for 48 hour and extracted. The extracts from the soxhlet extracts and that obtained from cold extracts for each sample were combined and they were re-extracted using chloroform to obtain chloroform soluble extract and store in sample bottle which was taken to NARIT, Zaria for GC-MS analysis.

GC- analysis were carried out with SHIMAZU Japan Gas Chromatography 5890-11 with a fused GC column OV 101 coated with polymethyl silicon $(0.25 \mathrm{~mm} \times 50 \mathrm{~m})$ and the conditions are as follows: Temperature programming from $80-200$ ${ }^{\circ} \mathrm{C}$ held at $80^{\circ} \mathrm{C}$ for I minute, rate $5{ }^{\circ} \mathrm{C} / \mathrm{min}$ and at $200{ }^{\circ} \mathrm{C}$ for 20 minutes. FID Temperature of $300{ }^{\circ} \mathrm{C}$, injection temperature of $250{ }^{\circ} \mathrm{C}$, carrier gas is Nitrogen at a flow rate of $1 \mathrm{CM}^{3} / \mathrm{min}$, split ratio 1: 75. GC-MS Gas chromatography Mass spectrum analysis were conducted using GC-MS QP 2010 Plus Shimazu Japan with injector Temperature at $230{ }^{\circ} \mathrm{C}$ and carrier gas pressure of 100kpa. The column length was $30 \mathrm{~m}$ with a diameter of $0.25 \mathrm{~mm}$ and the flow rate of $50 \mathrm{ml} / \mathrm{min}$. The eluents were automatically passed into the Mass Spectrometer with a detector voltage set at $1.5 \mathrm{kv}$ and sampling rate of 0.2 seconds. The Mass Spectrum was also equipped with a computer fed Mass Spectra data bank, HERMCE Z 233 M-Z centrifuge Germany was used. Reagents and solvents such as Ethanol, Chloroform, Diethyl ether, hexane all of analytics grade was obtained from Merck Germany.

\subsection{Anti-Microbial Analysis}

The Micro Organisms, Pseudomonas Aureginosa, Staphylococcus Aureus, Escherichia Coli, Salmonela Typhi, Candida Albicans and Aspergillus Niger were used for the analysis. They were obtained from the stock cultures of the Federal Medical Centre Umuahia cultures and were brought to the laboratory and were resuscitated in peptone water and thereafter subcultured into nutrient agar medium and incubated at $37{ }^{\circ} \mathrm{C}$ for $24 \mathrm{hrs}$ (Okigbo and Omodamiro 2006).

\subsection{Antibacterial Assay}

The test solution of each extract was Prepared by dissolving $0.1 \mathrm{~g}$ of the plant extract separately in $1.0 \mathrm{~cm}^{3}$ of dimethyl sulphoxide (DMSO) to get a concentration of $100 \mathrm{mglcm}^{3}$. The antibacterial activity was performed by filter paper disc diffusion technique. Filter paper disc (Whatman No $1.6 \mathrm{~mm}$ diameter) were placed in glass petridishes and sterilized in hot air oven (Ekundayo and Ezeogu, 2006). The media (10 g nutrient Agar in $200 \mathrm{~cm}^{3}$ distilled water, auto-claved at $115{ }^{\circ} \mathrm{C}$ for 30 minutes) was cooled to $50{ }^{\circ} \mathrm{C}$. The sterile nutrient Agar media were poured into the sterile petridish and allowed to solidify. The bacteria were swabbed with a sterile wire loop. Each disc was impregnated with $0.2 \mathrm{~cm}^{3}$ of plant extract standard, Ciprofloxacin was used as a control on a disc with DMSO $100 \mathrm{mg} / \mathrm{cm}^{3}$. The disc was used after drying them in an incubator at $40{ }^{\circ} \mathrm{C}$ to remove any trace of solvent (Anishmon and Toji 2005). Discs were introduced into the surface of the medium. The plates were microbated at $37^{\circ} \mathrm{C}$ for $24 \mathrm{hrs}$ to obtain zones of inhibition. The experiments were repeated three times for each extract and twice for reference antibiotics to minimize error and the average of these values were recorded.

\subsection{Minimum Inhibitory Concentration}

(MIC) the minimum inhibitory concentration of the extracts was determined by incorporating constant volume 0.2 $\mathrm{cm}^{3}$ of each diluent of the extracts into the perforated disc on a seeded nutrient agar plate as described in the anti-microbial susceptibility test section (Okigbo and Omodamiro 2006). $0.1 \mathrm{~g}$ of each extract was dissolved in $1 \mathrm{~cm}^{3}$ of DMSO to obtain 100 $\mathrm{mg} / \mathrm{cm}^{3}$. This concentration of DMSO was then double to obtain $50 \mathrm{mg} / \mathrm{ml}$, then double again to obtain $12.5 \mathrm{mg} / \mathrm{cm}^{3}$ and again to obtain $6.25 \mathrm{mg} / \mathrm{cm}^{3}$. Each concentration was then used in the method earlier described to obtain zone of inhibition. The least concentration that showed inhibitory zones was taken as the MIC.

\section{Result and Discussion}

\begin{tabular}{|c|c|}
\hline Constituent & Leaf \% \\
\hline Alkaloid & 0.48 \\
Flavonoid & 0.86 \\
Saponins & 0.66 \\
Phenols & 0.024 \\
Tannins & $0.85 \mathrm{ppm}$ \\
\hline
\end{tabular}

Table 1: Phytochemical Content of Newbouldia Laevis Leaf

Newbouldia laevis contains $0.48 \%$ alkaloid. Alkaloid ranked the most efficient therapeutically significant plant substance. Pure isolated alkaloids and their synthetic derivatives are used by Etinomedicinal practitioners for their analgesic, antispasmodic and bactericidal effects (Okwu and Okwu 2004). They exhibit marked physiological activity when administered to animals, the high alkaloid content of these samples may be the reason for their use in the treatment of cough, wounds, rheumatism and skin infections. Most samples containing alkaloid are used in Nigeria for the treatment of malaria and fever. (Adesegun and coker 2001). The saponin content of Newbouldia Laevis leaf was found to be $0.66 \%$ the high saponin content fortifies the use of the extract from these plants in the treatment of wounds. Some of the general characteristic of saponins 
includes formation of forms in aqueous solutions, hemolytic activity and cholesterol binding properties (Okwu 2005); Sodipo et al (2000). Saponin has the natural tendency to ward off microbes and this makes them good candidates for treating fungals and yeast infections. These compounds served as natural antibiotic, helping the body to fight infections and microbial invasion. The flavonoid content of Newbouldia Laevis Leaf is $0.86 \%$. flavonoids are distributed group of polycyclic compounds characterized by a common Benzo pyrone ring structure that has been reported to act as antioxidants in many biological systems. The family encompasses flavonoids, flavones, chalcones, catchins, anthocyanidins and isoflavonoids (Okwu and Aluwo 2008). In addition to their free radical scavenging activities, Flavonoids have multiple biological activities including vasodilatory, anti-carcinogenic, anti-allergic, antiviral, estrogenic effects as well as being inhibitors of phospholpase $\mathrm{H}_{2}$, cycloxygenase, glutathione reductase and xanthine oxidase. (Saleh et al 1995; Del Rio et al. 1997; Okwu 2004), they support lactogenecity. These properties therefore support the use of Pentaclethra Macrophylla in cancer therapy. (Asoegwu et al .2006). Flavonoids in intestinal tracks lower the risk of heart diseases. As anti-oxidant, favonoids provide anti-inflammatory actions.

The phenolic content of Newbouldia Laevis Leaf was $0.024 \%$. There is a growing interest in polyphenolic compounds as therapeutic agents against many diseases such as cardiac and cerebral ischemic, arteriosclerosis and rheumatic or pulmonary diseases. (Saleh 1995, Middletone and Kandaswani 1992). The activated phagocytic cells are known to produce potentially destructive oxygen species like super oxide anion $\left(\mathrm{O}^{2-}\right)$, hydrogen peroxide $\left(\mathrm{H}_{2} \mathrm{O}_{2}\right)$ and Hypochloric acid $(\mathrm{HOCl})$ during chronic inflammatory disorder. (Okwu and Aluwo 2008). Many polyphenolics are known to exhibit antioxidant properties, they are free radical scavengers. Phenolic flavonoids are also excellent hydroxyl scavengers. These properties promote health, and prevents certain chronic disorders such as cancer, cardiovascular diseases, diabetics and arthritis. The presence of phenols means that these extracts could act as anti-inflammatory, anti-clothing, anti-oxidants, immune enhancers and hormone modulators. Phenols have been the subject of extensive research as disease preventives. (Saleh et al 1995, Duke 1992). The have the ability to block specific enzymes that cause inflammations. They modify the prostaglandin pathways and thereby protect platelets from clumping.

The Tannin content of Newbouldia Laevis was $0.85 \%$. Tannins have astringent properties, hastening the healing of wounds and inflamed mucous membrane (Okwu and Okwu 2004). The presence of Tannins in these samples supports their use in treating wounds, varicose ulcers, hemorrhoids, frost bites and burns in herbal medicine

\begin{tabular}{|c|cc|c|}
\hline Organism & \multicolumn{2}{|c|}{ Zone of Inhibition } & Minimum Inhibition \\
\hline & (mm) & CPRO & Concentration $(\mathrm{mg} / \mathrm{g})$ \\
\hline Pseudomonas Aeruginosa & 12 & 26 & 6.5 \\
Staphyloccus aureus & 13 & 12 & 12.5 \\
Escherichia coli & 15 & 16 & 12.5 \\
Salmonella typhi & 17 & 19 & 6.5 \\
Candida albicans & 11 & 22 & 12.5 \\
Aspergillus Niger & 14 & 18 & 12.5 \\
Penicillium & 12 & 19 & 6.5 \\
\hline
\end{tabular}

Table 2: Anti-Microbial Result of Newbouldia Laevis

Key: Ciproflaxin Rep as Cpro

The leaf extract of Newbouldia laevis was used to inhibit the growth of Pseudomonas Aeruginosa,12mm Staphylococcus aureus,13mm Escherichia coli,15mm Salmonella typhi17mm, Candida albican11mms, Aspergillus, Niger $14 \mathrm{~mm}$ and Penicillium.12mm Results obtained showed high inhibition of_Salmonella typhi, Eschericia coli and Aspergillus Niger. Table (2), the minimum inhibitory concentrations are as follows, $6.5 \mathrm{mg} / \mathrm{g}, 12.5 \mathrm{mg} / \mathrm{g}, 12.5 \mathrm{mg} / \mathrm{g} .12 .5 \mathrm{mg} / \mathrm{g} 6.5 \mathrm{mg} / \mathrm{g}, 2.5$ $\mathrm{mg} / \mathrm{g} 12.5 \mathrm{mg} / \mathrm{g}$ and6.5 mg/g for P. aureginosa, Staphyloccus aureus, E. coli. Salmonella, C. albicans, A. niger and Penicillium respectively. These organisms are implicated in causing uterine wall disorder, fever and inflammations of cells. The inhibitions were comparable to the activity of standard antibiotic ciproflaxin. This supports the finding of Usman and Osuji (2007) in using the crude extracts in the treatment of stomach disorder, diarrhea, dysentery and wound treatment. High fever in children usually lead to convulsion, therefore the work of Akunyili (2000) on the usefulness of the leaf extract in treating convulsion is been given credence to. Okwu and Orji (2004) had indicated that the leaf extract could be used in would dressing and treatment of stomach ache. Therefore, this extract could be implication in the treatment of sexually transmitted disease (STD) such as syphilis. 


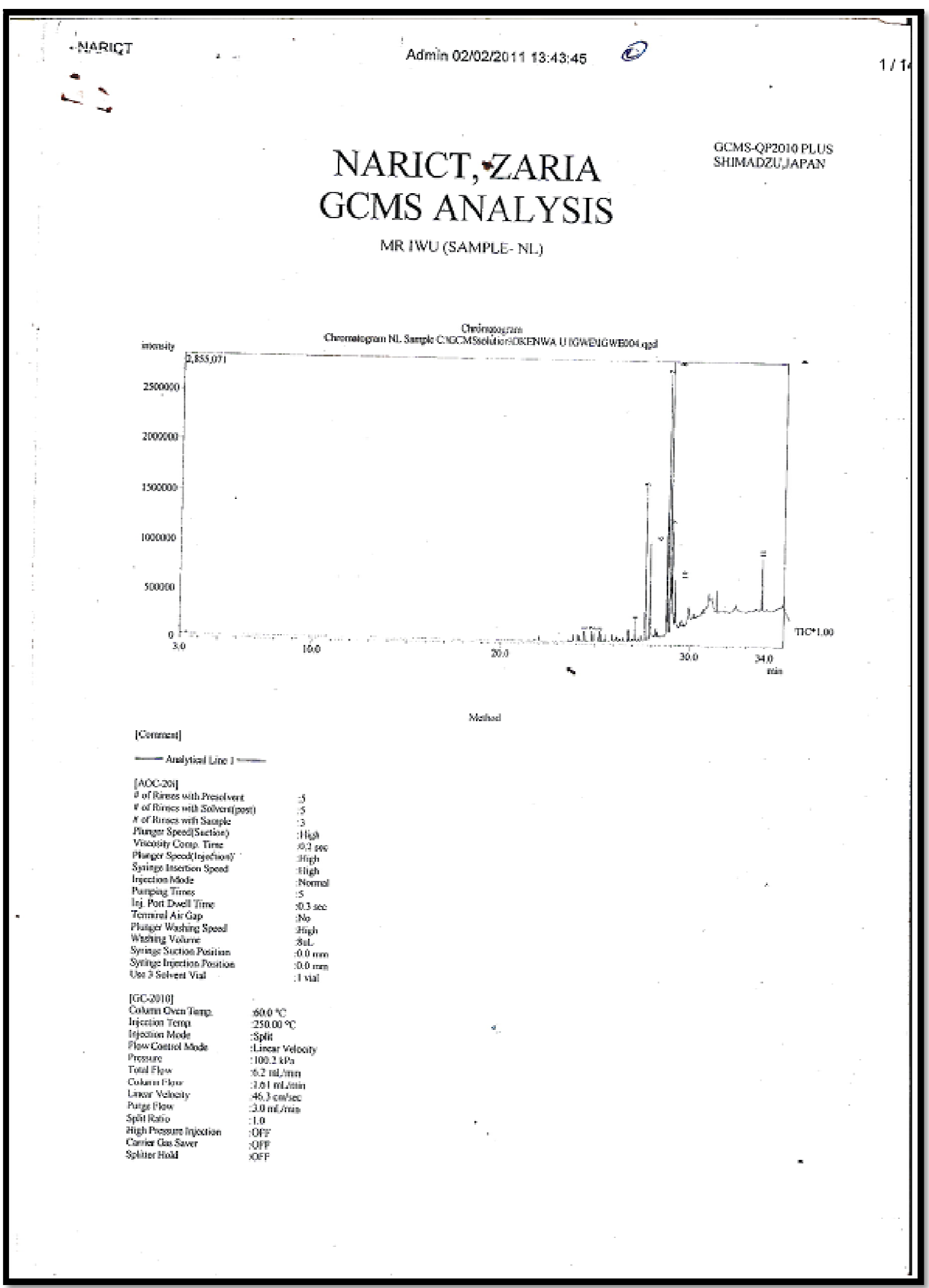

Figure 1: GC/ MS Spectrum of Newbouldia Laevis Leaf 


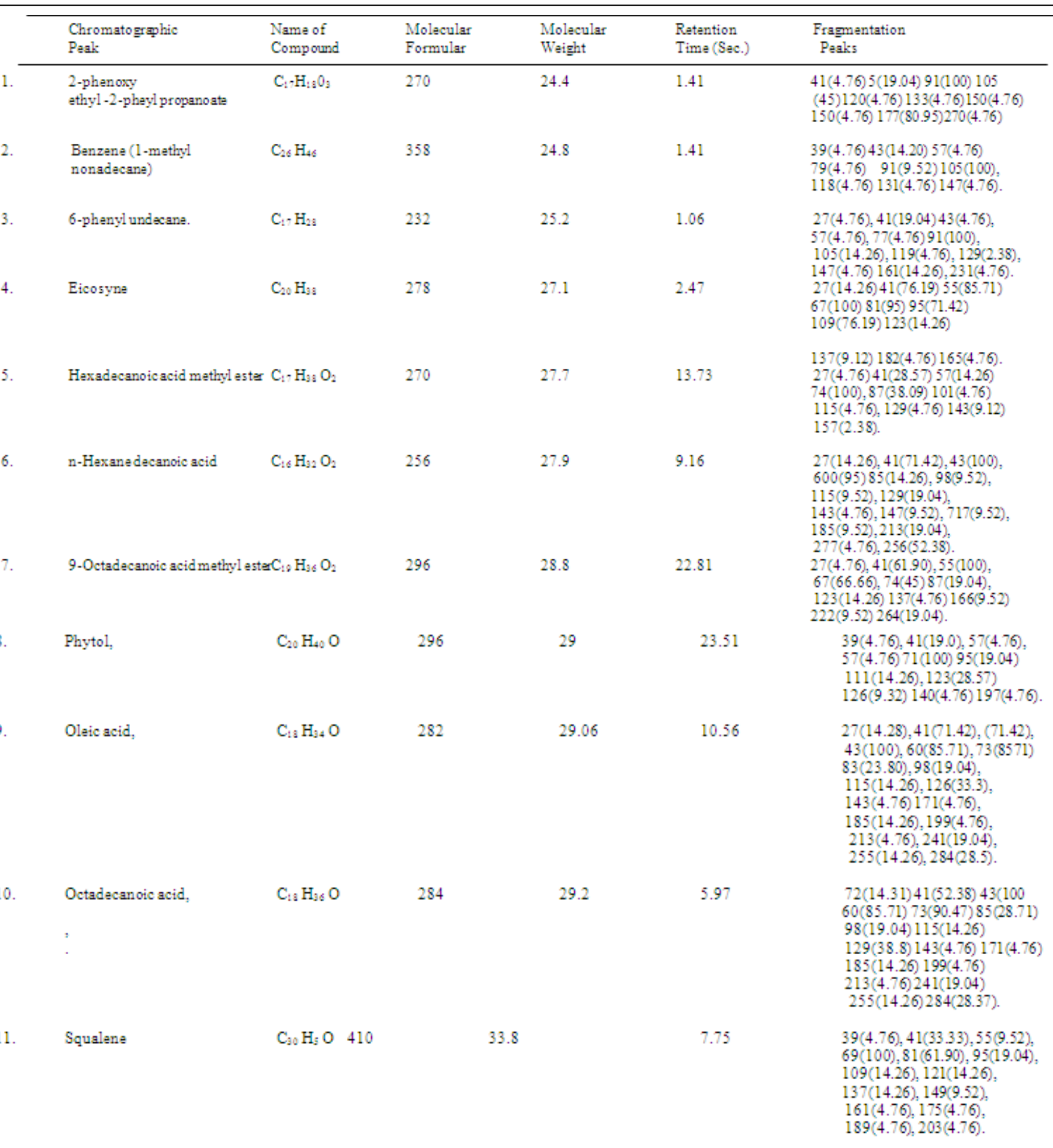


<smiles>OC(CCc1ccccc1)OCCOC1CCCCC1</smiles>

[1]2- phenoxyethyl -3- phenyl p ropanoate<smiles>CCCCC(CCC)c1ccccc1</smiles>

[3] 6-phenyl undecane

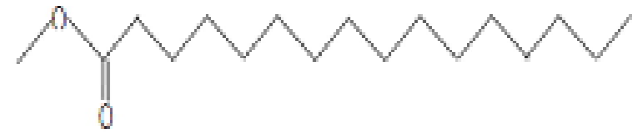

[5] Hexadeanoic methyl ester<smiles>CCCCCCCCCCCCCCCC(=O)OC</smiles>

7] z-9- Octade canoic methyl ester

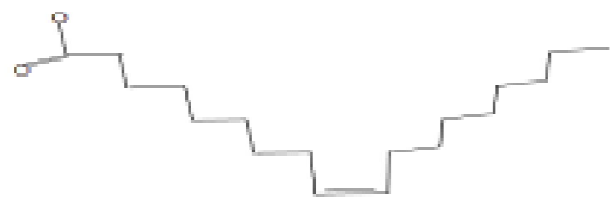

[9] Oleic acid

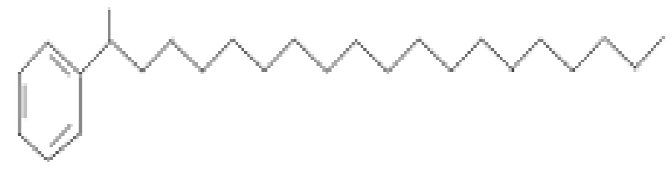

[2] Benzene [-1-methyl nonadecane]

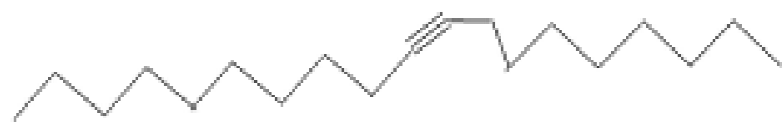

[4] 9-eicosyne

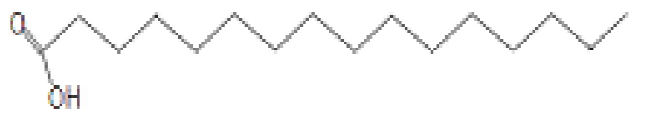

[6] n- hexanedecancic acid

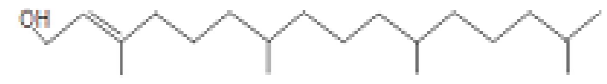

[8] 3,7,11,15-tetramethyl-2-Hexadecen-1 - ol (phytol)

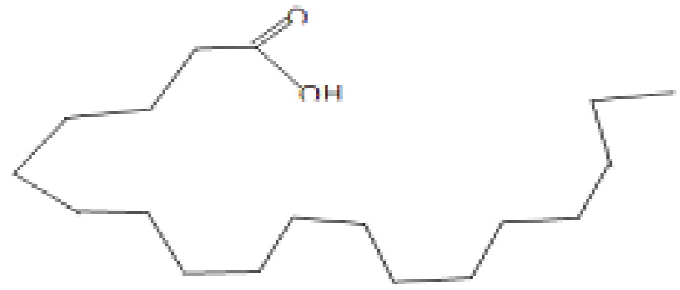

10] Octadecanoic acid 


\section{Discussion}

The spectrum obtained from the leaf extract of Newbouldia laevis leaf showed 11 absorption peaks. Peak 1 occurred with $\mathrm{m} / \mathrm{z} 270$ and formula $\mathrm{C}_{17} \mathrm{H}_{18} \mathrm{O}_{3}$ having $1.4 \%$ content and named 2-Phenoxy ethyl -3-phenyl propanoate [1]. Peak 2 appeared at $\mathrm{m} / \mathrm{z} 358$ with the formula $\mathrm{C}_{26} \mathrm{H}_{46}$ with \% oil content of 1.41 and named Benzene (-1-methyl nonadecyl) [2]. Peak 3 appeared at $\mathrm{m} / \mathrm{z} 236$ corresponding to the formular $\mathrm{C}_{17} \mathrm{H}_{26}$ having $1.06 \%$ oil content and named 6-Phenyl Undecane. [3]. Peak 4 occurred at m/ z 278 with the formular $\mathrm{C}_{20} \mathrm{H}_{38}$ with $2.47 \%$ oil content and named Eicosane [4]. Peak 5 occurred at m/ z 270 with the formula $\mathrm{C}_{17} \mathrm{H}_{38} \mathrm{O}_{2}$ having $13.7 \%$ oil content and is named Hexadecanoic acid methyl ester [5]. Peak 6 occurred at m/ z 256 with the formula $\mathrm{C}_{16} \mathrm{H}_{32} \mathrm{O}_{2}$ with $9.16 \%$ oil content and named n-Hexane decanoic acid [6]. Peak 7 occurred at m/ z 296 with formula $\mathrm{C}_{19} \mathrm{H}_{36} \mathrm{O}_{2}$ and $22.81 \%$ oil content and named as z-9 -Octadecanoic acid [7] Peak 8 occurred at m/ z 296 with formula $\mathrm{C}_{20} \mathrm{H}_{40} \mathrm{O}$ having $23.51 \%$ oil content and is named 2-Hexadecen-1-ol [8]. Peak 9 occurred at M/ z 282 with the formula $\mathrm{C}_{18} \mathrm{H}_{34} \mathrm{O}, 10.56 \%$ oil content and is named Oleic acid [9]. Peak 10 occurred at $\mathrm{M} / \mathrm{z} 284$ with formula $\mathrm{C}_{18} \mathrm{H}_{36} \mathrm{O}$ with $5.97 \%$ oil content and named Octadecanoic acid [10]. Peak 11 occurred at m/ z 410 with formula $\mathrm{C}_{30} \mathrm{H}_{50}$ and $7.75 \%$ and named Squalene [11]

\section{References}

i. Akunyili, D. N. (2000). Anticonvulsant activities of the ethanolic extract of Newbouldia laevis. Paper presented at the 2nd NAAP Scientific conference. 155-158

ii. Amechina. O.O (2003). Three minutes herbal treatment to reduce dental caries with Newbouldia laevis based extract. American journal of undergraduate research 2 (2):1-4.

iii. Amos, S. Binda,I, Vongtau,H, Chindo, B, Abbah,J, Sambo, N, Odin,E.M, Okwute, S.K, Akah,P, Wambebe,C, Gramaniel,K, (2002). Sedative effects of the methanolic leaf extract of Newbouldia Laevis in mice and rats. La Reference en Fournitue de documents scientifique 141:471-475

iv. Banhil, R.L, Dill, N.J, Millikan,C.E, Hasting, R.E (1984). Studies on the Ant inflammatory properties of Thalidomide effects on the polymorphonuclear leukocytes and monocytes.J.AM. Dermatol ii : 814-819

v. Boham,B.A and Kocipai,A.C. (1994). Flavonoids and condensed tannins from leaves of Hawaina Vaccinium and V.Calycinium.Pacific Sci 48; 458-463

vi. Del-Rio, A. Obdullio,B.G. Casfillo, J. Marin,F.G. Ortuno,A.(1997 ). Uses and properties of Citrus Flavonoids. J. Agric Food Chem 45; 4505-4515

vii. DukeJ. (1992) Handbook of Biological active phytochemicals and their activities .Boca Raton (FL) CRC Press 99-131

viii. Ekundayo,E.O. Ezeogu, L.I.(,2006). Evaluation of antimicrobial activities of Extracts of five plants used in Traditional Medicine in Nigeria. International Journal of Tropical Medicine 3;93-96

ix. Enitone,E.B., Upe,S, Zaleikha,A and Nworgu,M.( 2010 ). Invitro determination of the mechanism of uterine stimulatory effects of Newbouldia laevis. Informa Healthcare 808-815

x. Harbone, J.B .(1973). Phytochemical methods. Chapman and Hall London 110-113

xi. Iwu.M.M, (2000) Handbook of African medicinal plants. London CRC Press Inc. 19

xii. Lewis,.W. and Manony ,P.F. ,(1977). Medical Botany; Plants Affecting Man Health.New York. USA. John Wiley and Sons 240

xiii. Middleton ,E. and Kandaswani, H. (1992). Effects of Flavonoid on immune and Inflammatory function. Biochemistry and pharmacology 43;1167-1172

xiv. Obadoni,B.O. and Ochuko,P.O (2001). Phytochemical studies and comparative efficacy of the crude extract of some homeostatic plants in Edo state and Delta state of Nigeria .Global journal of Pure and Applied Sciences 8:203-208

xv. Ogunlana ,O.E and Ogunlana, O.O, (2008). Invitro Assessment of Antioxidant Activity of Newbouldia Laevis, Journal of Medicinal Plants Research 2 (8) :176-179

xvi. Okigbo .R.N and Omodamiro .O.D.( 2006). Journal of herb, spices. Medicinal plants 2;117

xvii. Okwu,D.E, (2004). Phytochemicals and mineral content of indigenous spices south of eastern Nigeria. Journal of sustainable Agriculture and Environment 6: 30-37

xviii. Okwu.D.E.and Okwu.M.E.2004 Chemical composition of Spondia Mombium Linn plant parts. J.Sustain.Agric Environs $6(2) ; 30-37$

xix. Okwu, D.E, (2005) Phytochemical and mineral content of two Nigeria Medicinal plants. International Journal of Molecular Adv.Sci. 375-381

xx. Okwu, D.E. and Orji. B. (2007) Phytochemical and Nutritional composition of selected Tropical edible grains of Northern Nigeria Food 4 (2) 347-350

xxi. Oliver-Bever, B. (1986). Medicinal plants in Tropical West Africa London Cambridge Uinversity Press. 117-118

xxii. Saleh,W. Miller,N.J, Paganga,G, Tijburg,G.P. Bolwel,E, Rice,E. Evans, C (.1995). Polyphenolic Flavonoids as scavangers of aqeous phase radicals as chain breaking anti 0xidants. Arch -Bio Chem Biorh 2 ;339-346

xxiii. Sodipo,O.A and Akiniyi,J.A, (2000). Studies on certain characteristics of Extracts from bark of Pansinysstalia Macrucerus (K.Schum) pierre Exbeille. Global.J.Pure and Applied Sci 6 ; 83 -87

xxiv. Tanko,Y, Kamba,B, Saleh,M.I.A, Musa,K, and Mohammed ,A, (2008). Antinociceptive and Anti inflammatory activities the ethanolic flower extract of Newbouldia Laevis in mice and rats. International Journal of Applied Research in Natural Products 1(37):13-19 
xxv. Usman, H. and Osuji, J.C. (2007). Phytochemical and Invitro antibacterial assay of the Leaf extract of Newbouldia Laevis. African journal of Traditional CAM 4: 476-480

xxvi. Van-Burden.T.P. and Robinson.Formation of complexes between protein and Tannin acid . Journal of Agric .Chem.1;77-82 